INTERNATIONAL JOURNAL OF RESEARCHES IN BIOSCIENCES, AGRICULTURE AND TECHNOLOGY

(C) VISHWASHANTI MULTIPURPOSE SOCIETY (Global Peace Multipurpose Society) R. No. MH-659/13(N) www.vmsindia.org

\title{
STUDY OF PAUCI BACILLARY AND MULTI BACILLARY LEPROSY IN ASHTI TAHSIL, DIST.WARDHA (M.S).
}

\author{
A. S. Patankar ${ }^{1}$, S. S. Nimgare ${ }^{2}$, U. W. Fule, P. M. Telkhade 3 \\ ${ }^{1}$ Mahatma Gandhi Ayurved College, Salod, Dist.Wardha. \\ ${ }^{2}$ Hutatma Rashtriya Arts \& Science College, Ashti, Dist. Wardha. \\ ${ }^{3}$ Arts, Commerce and Science College, Tukum, Dist. Chandrapur. \\ patankar.kargi@gmail.com
}

\begin{abstract}
:
The present investigation was carried out to study Multi bacillary and Pauci bacillary leprosy cases in different villages of Ashti Tahsil, Di. Wardha (M.S.) The present investigation showed that 120 cases of Paucibacillary leprosy (PB) were identified since 1990 to 2014 of which 89 were males and 31 were females while only 04 cases of Multi bacillary leprosy (MB) were identified. Prevalence of leprosy was found less in females as compared to males. There were 41 cases of follow up of which 16 were males and 25 were females. The effective treatment of leprosy was given in the form of Multi Drug Therapy (MDT) a combination of two or three drugs, Rifampicin, Dapsone and Clofazimine.

Keywords: Leprosy, Multi bacillary, Pauci bacillary, MDT, Ashti.
\end{abstract}

\section{Introduction:}

Leprosy is a millennial disease, a Biblical one. And its victims have been segregated and discriminated against forever.People also don't like to talk about it, but leprosy is a very common disease in a number of countries like Brazil.Even worse, children are the silent victims of leprosy, because adults infect them easily; and a delay in diagnosis can lead to severe and permanent damage, including paralysis of the hands. The solution is to make the eradication of this disease a priority.Leprosy isn't widespread like malaria or TB, but it is debilitating, and there are traumatic repercussions.It shouldn't be this way, and we can treat this disease. People should not be losing their right to healthy lives to this.

Stopping the spread of leprosy is essential, and we need to make a concerted effort to diagnose it. We have developed a way to rapidly diagnose the disease. And, once we identify affected people, we musttreat them so they don't develop irreversible neurological problems.The key barrier is an available diagnostic test that we can implement early on. We have therapeutics now, but they are often administered too late and have to be given for a long time in order to work. A better answer is better treatment of an early infection. This would be a big improvement, because now we often apply a mass antibiotic to people - whether they're infected or notI look at 2013 positively. We have better treatments that are getting even better, and we are confronting leprosy in a strong and smart way.

The present investigation deals with the study of Pauci bacillary and Multi bacillary leprosy cases in AshtiTahsil, Di. Wardha. (M. S.). since 1990 to 2014.

\section{Methods of Leprosy Detection:}

Leprosy is caused by a bacteria Mycobacterium leprae. It is strongly acid fast ( it is stained red by a dye called carbolfuschin and the red colour cannot be removed either by acid or alcohol). The presence of the bacilli can be demonstrated by taking smears from skin/nasal mucosa (slitting the skin and scraping the material with blade and spreadind it on a glass slide, staining it with the ZiehlNeelsen method and examining under the microscope ).Usually skin smear in leprosy is taken from three sites ( skin lesions, both ear lobes). The smears may be either positive or negative for M. leprae. Leprosy patients whose smears are positive are more infectious than those who are not.

\section{Results and Discussion:}

After making a diagnosis of leprosy, the patients were grouped in two categories depending on certain characteristics (Table-1). This was important in selecting the correct combination of drugs for a given patient.

The present investigation showed that 120 cases of Paucibacillaryleprosy (PB)) were identified since 1990 to 2014 of which 89 were males and 31 were females (Fig.2.Table-2) while only 04 cases of Multibacillary leprosy (MB) were identified ( Fig. 1). Prevalence of leprosy was found less in females as compared to males. There were 41 cases of follow up of which 16 were males and 25 were females.

Leprosy is among the world's oldest and most dreaded diseases and it has been synonymous with stigma and discrimination due to the hideous deformities it produced, mystery around its aetiology and transmission and lack of any effective remedy till recently. The results of present study showed that though leprosy 
control started with the use of multi drug therapy (MDT) for last three decades, however a parallel drop in the incidence or new case detection rate (NCDR) had not occurred (NLEP Report, 2007 ). From 1994 through 2011, more than 100,000 new cases were detected annually, of whom maximum case load was from India.

Efforts had been made to reduce deformities through early detection, self care, physiotherapy and reconstructive surgery particularly for the treatment of nerve damage in leprosy (Van Veen et. al., 2009). Penna et, al.(2005) and Walker et. al. (2007) studied the role of thalidomide in the treatment of erythema nodosumleprosum. Aberdein and Singer (2006) also studied the use of corticosteroids in leprosy infection.Evaluating the role of immunotherapy and immunoprophylaxis would also lead us to better understanding of their mode of action. Further molecular analysis of Mycobacterium leprae genome might provide the requisite basis for all this.

Many workers studied about early diagnosis of leprosy (Moet et. al.,2004, Nicholls et. al.,2006 ) still there is need for research on tools for early diagnosis, short and effective treatment and prevention of deformities and disabilities. Though researches had been made to reduce the stigma and discrimination (VanBrakel, 2003, Heijnders and Van Dermeij, 2007) related to leprosy but the current reality is that there is a need to sustain and provide quality leprosy services to all persons through general health services, including good referral system. All these provisions in the integrated health care approach will go a long way in further reducing the stigma. It is hoped that with the efforts of all the stake holders and strong political will, the disease will be eradicated in the near future.

Table -1: Criteria for grouping leprosy types.

\begin{tabular}{|l|l|l|l|}
\hline & Characteristics & Paucibacillary (PB) & Multi bacillary (MB) \\
\hline 1 & Skin lessions & $1-5$ lessions & 6 and above \\
\hline 2 & Peripheral nerve & No nerve/only one nerve involvement & More than one nerve \\
\hline 3 & Skin smear & Negative at all sites & Positive at any site \\
\hline
\end{tabular}

Table-2 : Review of Pauci bacillary cases in different villages of AshtiTahsil ,Di- Wardha.

\begin{tabular}{|c|c|c|c|c|}
\hline SR.No. & Name Of The Village & Total & Male & Female \\
\hline 1 & Ashti & 24 & 16 & 08 \\
\hline 2 & Chistur & 05 & 04 & 01 \\
\hline 3 & Belora & 02 & 01 & 01 \\
\hline 4 & Sirkutani & 05 & 05 & 00 \\
\hline 5 & Sujatpur & 01 & 01 & 00 \\
\hline 6 & Antora New & 03 & 03 & 00 \\
\hline 7 & Parsoda & 05 & 03 & 02 \\
\hline 8 & Jaitapur & 03 & 01 & 02 \\
\hline 9 & Daultpur & 01 & 01 & 00 \\
\hline 10 & Ganeshpur & 01 & 01 & 00 \\
\hline 11 & Chincholi & 02 & 02 & 00 \\
\hline 12 & LahanArvi & 04 & 04 & 00 \\
\hline 13 & Kinhala & 04 & 02 & 02 \\
\hline 14 & Chamala & 02 & 02 & 00 \\
\hline 15 & Sirsoli & 02 & 02 & 00 \\
\hline 16 & Ajitpur & 01 & 01 & 00 \\
\hline 17 & Ranwadi & 02 & 01 & 01 \\
\hline 18 & Tekoda & 01 & 01 & 00 \\
\hline 19 & Harishwada & 03 & 01 & 02 \\
\hline 20 & Bambrda & 01 & 01 & 00 \\
\hline 21 & Khadki & 02 & 02 & 00 \\
\hline 22 & Belora & 03 & 02 & 01 \\
\hline 23 & Anandwadi & 02 & 02 & 00 \\
\hline 24 & Bharswada & 09 & 05 & 04 \\
\hline 25 & Bhishnur & 01 & 01 & 00 \\
\hline 26 & Kakaddhara & 08 & 05 & 03 \\
\hline 27 & Ramdara & 11 & 07 & 04 \\
\hline 28 & Talegaon SP & 12 & 12 & 00 \\
\hline
\end{tabular}




\section{FII. 1 MUL IILALILLAKY LASL5}

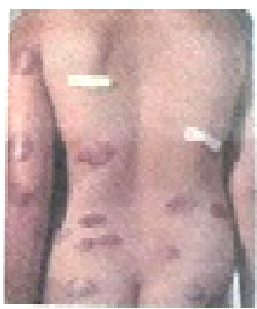

Muliple, aharply odemarcalter, scaly reoden brown plaqques: these subsiding lesions are anly firtilaly anaosthotion. (Borde rline: Tubanculvid (BT))

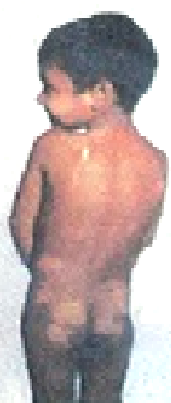

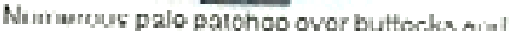
Irnink. Nomb honed MO Leprusy (Nummos palu palcheg)

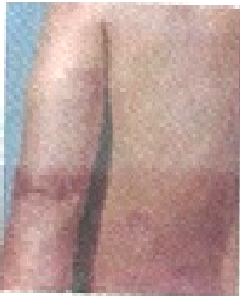

Numerous and widerniead hurfluriling-tyes placuas, arniular lesiurs, papulog and thaculos; wrintra uf lealyu lasione gnow some loss of semeation, Borderlin Lepmomatous (BL)]

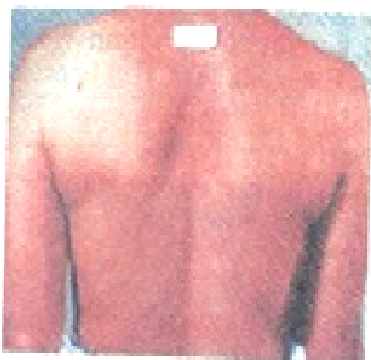

Pulliy unirom symmetrically distribulad,

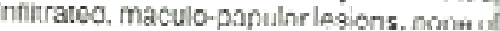
which show benaory impatument. (Gorderline Levunatous (BL)

Fig. 2 PAUCIBACILLARY CASES

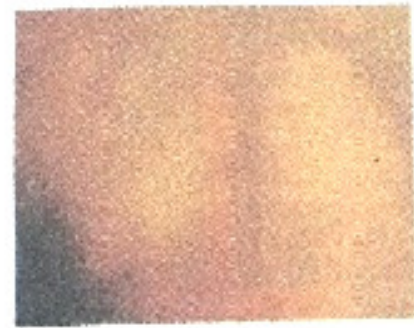

Theso vague, patches, with roduced o louring (hypopigmentation) compared to the surrounding skin. were found on the left shouider region. They increased in size during a period of obserwation and showed loss of sensation to cotton wool and pinprick, Paucibacillary (PB) Leprosy.

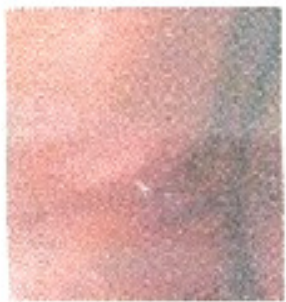

Well detined hypopigmenled lesion with dry surface and moderately raised granular margins: complctely anaesthetic. (Tubertoloid (TT))

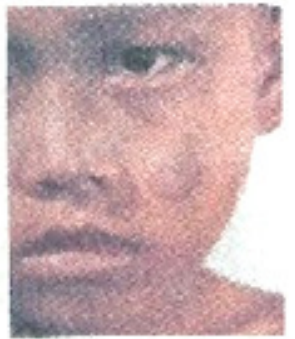

Well defined, dry and rough-suriaced plaque on cheek, inscnsitive to touch and pain; note papulo- nodular lesions near eyc and upper lip. To be categurized as $\mathrm{P} \cdot \mathrm{B}$ if there are more patchos on other parts of the bocty.

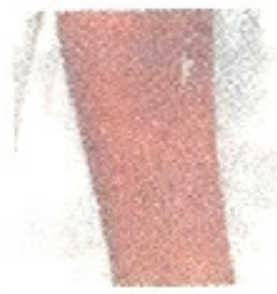

A large area un lower part of the forcam, with vague edges. Lasion increased over 2 months observalion showing reciuced sensutions. Paucibacillary Leprosy. 


\section{Conclusion:}

We must also safely immunize everyone in the household who has had contact with leprosy to stop the spread to others. leprosy's victims often lead lonely and isolated lives, because of the stigma attached to the disease - a stigma that is often affixed to the entire family. So it's important to remember that this long-term, destructive and debilitating illness has serious consequences in addition to death. The most important thing we can do is provide new tools, so we can be proactive in detecting and treating the infection early.

\section{Acknowledgement:}

Authers are thankful to P.H.C., Ashti and NLEP, Amravati for providing essential material to conduct this study.

\section{References:}

Aberdein, J. and Singer, M. (2006). Critical review : A systematic review of corticosteroid use in infections. Critical Care .10 203 (available online from

http://ccforum.com/content/10/1/203).

Heijnders, M. and Van Der Meij, S. (2007). The fight against stigma an overview of stigmareduction strategies and interventions. Psychology, Health and Medicine. 113 pp.353363.

Moet, F. J., Meima, A., Oskam, L. and Rechards, J. H. (2004). Risks factors for the development of clinical leprosy among contacts and their relevance for targated interventions. Leprosy Review 75 pp.310-326.

Nicholls, P.G., Ross, L., and Smith, W. C. S. (2006). Promoting early detection in leprosy: A literature review to identify proven potential interventions in addressing patient related delay . Leprosy Review. 77 pp. $298-310$.

NLEP- Programme Implementation Plan (PIP) for continuation of NLEP (from 1st April 2005 to 31st March 2007)- Ministry of Health \& Welfare, Government of India.

Penna, G. O.,Martelli, C. M. T., Stefani, M. M.A., Macedo, V. O., Maroja, M., and Chaul, A. (2005). Thalidomide in the treatment of erythema nodosumleprosum (ENL) : Systematic Review of clinical trials and prospects of new investigations. Anais Brasileiros de Dermatologia. 805pp. 511-522.

Reinar, 1. M.,Forsetlunde, L., Bjorndal, A. and Lockwood, D. (2009). Interventions for skin changes caused by nerve damage in leprosy (Review).The Cochrane Library 2009 Issue 2.

Van Brakel, W. H. (2003). Measuring leprosy stigma- A Preliminary Review of the Leprosy Literature. International Journal of Leprosy and Other Mycobacterial diseases. 71 3pp.190-197

Van Veen, N. H. J.,Schreuders, T. A.R., Theuvenet, W. J.,Agrawal, A. and Richards, J. H. (2009). Decompressive surgery for treating nerve damage in leprosy .(Review) The Cochrane Library 2009 Issue 2.

Velema, J.P., Ebenso, B. and Fuzikawa, P. I. (2008). Evidence for the effectiveness of rehabitation in the community programmes. Leprosy Review. 79 pp. 65-82.

Walker, S.L., Waters, M.F.R. and Lockwood, D.N.J. (2007). The role of thalidomide in the management of erythema nodosumleprosum. Leprosy Review 78 pp. 197-215. 